\title{
Sir Thomas Lewis redivivus: from pebbles in a quiet pond to autonomic storms
}

\author{
THOMAS N JAMES
}

\section{From the Callaway Laboratory of the Department of Medicine, University of Alabama Medical Center, Birmingham, Alabama, USA}

History without heroes would make dull reading indeed. In today's egalitarian world there is a regrettable shortage of heroes, making each of us appreciate all the more those genuine ones from earlier times. It is now. just over 60 years since Sir Thomas Lewis chaired the first meeting of the British Cardiac Club, which was later to become the British Cardiac Society. Today, nearly four decades after his death, Lewis still inspires everyone in what may be called civilised medicine, for he led the way in bringing scientific principles and methods into the mainstream of clinical practice.

All his life Lewis continued to see patients but never strayed far from his love for research, seeking experimental verification (or disproof) for hypotheses derived from clinical observations. This attractive combination of clinical skills and scientific inquiry is becoming vanishingly rare and, some say, in imminent danger of extinction. The "impossibility" of being expert at the bedside as well as the bench is lamely excused on the basis of the complexity of modern science, but I suspect that a more valid explanation may be too few Lewises today. There has never been an abundance of men with such dedication, intelligence, energy, and clarity of perception, but it is largely by the aura of their kind that others are lured into the way.

Lewis was fond of aqueous metaphors, often speaking or writing of rushing streams and waterfalls, no doubt as a legacy from his youth in the beautiful land of Wales. He was also gifted in the choice of striking and unforgettable phrases to illustrate his scientific points, as indicated by his comparison of atrial excitation with the ripple formed when one tosses a pebble into a quiet pond. ${ }^{1}$ But to describe palpitation and hypertension so often associated with anginal pain it is difficult to think of a term more suitable than his "autonomic storm."

Based on the Thomas Lewis Lecture delivered to the autumn meeting of the British Cardiac Society, London, on 21 November 1983.

Requests for reprints to Dr Thomas N James, Callaway Laboratory of the Department of Medicine, University of Alabama Medical Center, Birmingham, Alabama 35294, USA.

Accepted for publication 14 February 1984
Of course, if Lewis was judged only from his publications it would be a flawed verdict and a grave injustice. In his time he stimulated and inspired several generations of young physicians to appreciate the beauty of clinical science. As much as any man then or since he showed how the scientific method must support the reasoned, compassionate, and intelligent care of patients. But surely one of his most becoming attributes was the durability of his friendship, which was carefully and selectively bestowed. Decades after they first met and collaborated in research the late Frank $\mathbf{N}$ Wilson of Ann Arbor could still evoke nostalgic memories of their watching birds together in Michigan.

Sir George Pickering, one of Lewis's last students and the first to deliver this eponymous lecture, often came to Birmingham (Alabama) to visit his old friend Tinsley Harrison. It was my privilege to act as his academic host on several of those occasions, during one of which he spied on my shelf a treasured early copy of The Mechanism and Graphic Registration of the Heart Beat. This led him to reminisce that his own copy was a wedding present from his mentor, with whom he was then working. Pickering further recalled for me how profoundly Sir James McKenzie had influenced the young Lewis, for example in the classic studies of atrial fibrillation, and I was reminded how the same McKenzie was also the stimulus to Sir Arthur Keith when he and Martin Flack discovered the sinus node. Ultimately, Pickering was to write a touching and memorable tribute to Lewis when he died. ${ }^{2}$ Although many must have known it when The Mechanism and Graphic Registration was a newer book, few today realise what a gold mine of references it contains. The 1003 citations not only serve as a generous acknowledgement of the contributions of others, they provide an invaluable overview of the origins for the scientific basis of cardiology.

On this occasion I want to consider certain familiar contributions of Lewis which have particular meaning for me because of my own work. Beyond that element of personal bias, I believe that those particular contributions also epitomise what he did so well and will serve to illustrate its contemporary relevance. Obser- 



Fig. 1 Photomicrographs of two different normal human sinus nodes. Periarterial distribution of the sinus node is marked with four arrows in (a). All of the tissue shown in (b) is sinus node. SVC, superior vena cava; CT, crista terminalis. van Gieson elastic stain; all magnifications are indicated with reference bars. 
vations from my own laboratory will be used to depict how Lewis's work relates to current concepts. As an outline for my remarks I have divided Lewis's works into three groups. The first group deals with the sinus node, atrial arrhythmias, and atrial conduction and represents what may be seen as his electrophysiological period. The second group includes clinical dysautonomic states, from the time when he became interested in the functional relation of the brain and the heart. The third group concerns the microcirculation, a logical outgrowth of the work on neural control of the cardiovascular system. Although these three arbitrary groupings do not exactly fit the calendar of his life, they come close to representing the early, middle, and later periods. Some overlap is obvious when one notes that the wartime studies of soldier's heart and neurocirculatory asthenia ${ }^{3}$ were followed more than a decade later by commentaries on Nothnagel's syndrome ${ }^{4}$ and angina pectoris. ${ }^{5}$

\section{Sinus node, atrial rhythms, and atrial conduction}

Since all electrical activity of the heart normally originates in the sinus node, it seems particularly fitting that Lewis's earliest major work dealt with that structure and its functional importance. ${ }^{6}$ There was a special timeliness for the paper, appearing as it did only a few years after the remarkably lucid and comprehen-

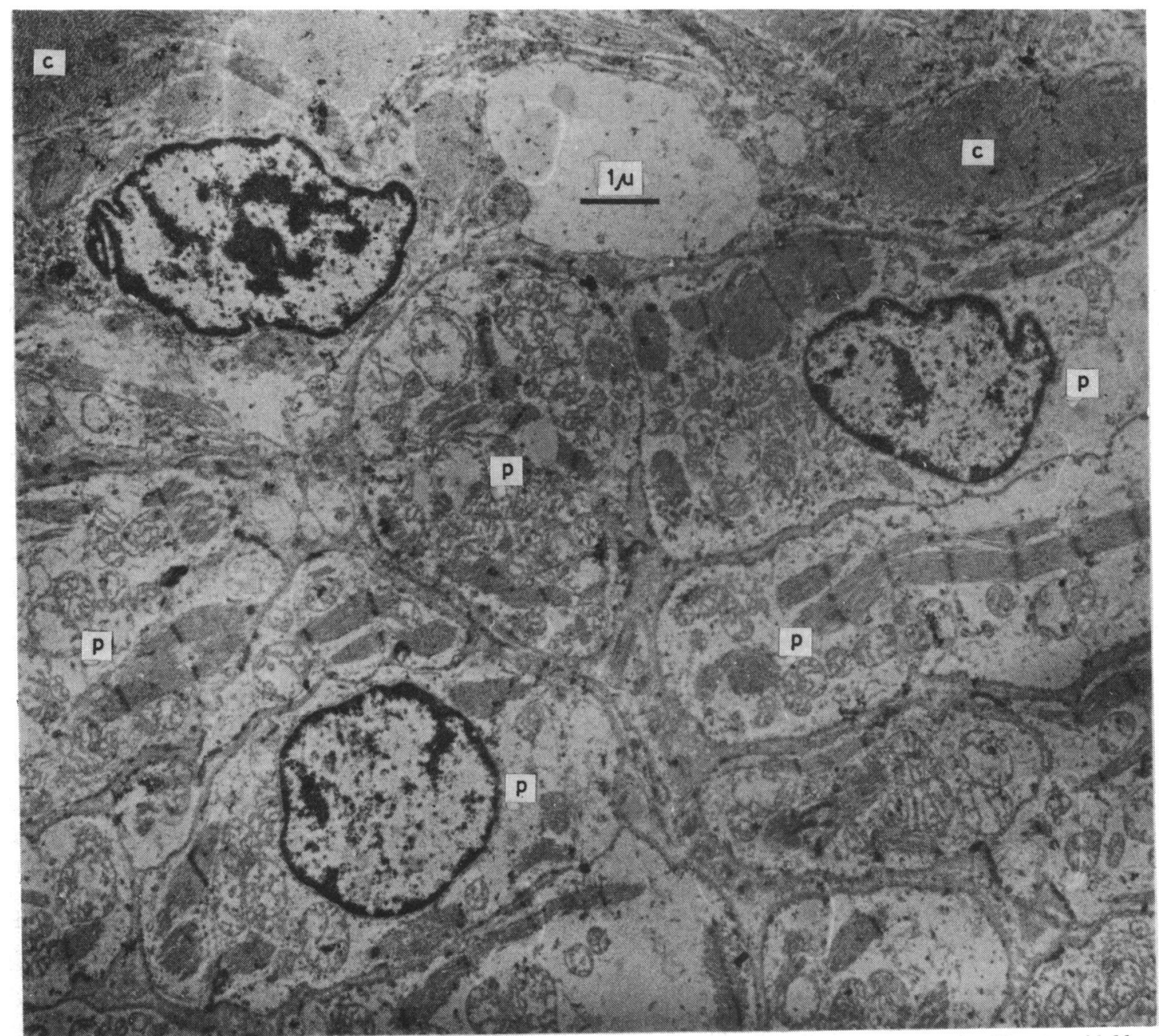

Fig. 2 Electron photomicrograph of a child's sinus node prepared with fixative about three hours post mortem. The unavoidable arefacts of glycogen depletion and similar changes do not obscure the well preserved intercellular junctions and myofibrils. Sufficient detail is retained to demonstrate the distinct features of $P$ cells $(p)$ in the sinus node of human hearts. $c$, collagen. 
sive report by Keith and Flack describing their discovery. ${ }^{7}$ Although the deductive logic by which Keith and Flack interpreted the functional significance of the sinus node was to prove correct, the experimental studies by Lewis and his colleagues gave valuable support. Some who disdain the subject of anatomy would say that the understanding of sinus rhythm was assured only when its physiological behaviour was defined, but this is as unfair as it is wrong. Lewis knew just what to study precisely because of the careful anatomical description by Keith and Flack. There is ample credit to be shared by both anatomists and physiologists.

In those days and even up until the middle of the century the histological composition of the sinus node was described as specialised "fibres." Once electron microscopy was available the discrete cellular structure of the myocardium became clear, and the idea of a fibre-filled syncytium was no longer tenable. It is now known that the sinus node ${ }^{8}$ is normally organised within a dense collagen framework surrounding a conspicuously large central artery (Fig. 1), leading Söderström aptly to describe the node as resembling an enormous adventitia of its artery. ${ }^{9}$ This periarterial disposition may serve a stabilising autoregulatory purpose. ${ }^{10}$ Within the collagen frame there are many capillaries and nerves and at least two special types of myocytes distinctly different from working myocardium and from Purkinje cells. ${ }^{11}$

Because both kinds of nodal myocytes are abundant in the sinus node but are so different from each other it is wrong to call either of them the nodal cell and probably unwise to call both of them that. The first type of cell is small, round or ovoid, has very few specialised intercellular junctions, and contains only sparse amounts of glycogen and hardly any organised sarcoplasmic reticulum. There is a paucity of myofibrils, which in turn contain few myofilaments and are randomly oriented within the cell. The small mitochondria vary in size and configuration, are conspicuously simple in structure with few cristae (Fig. 2), and are also randomly distributed within the cytoplasm. Owing to the small number of organelles and the minimum amount of glycogen these cells are pale and primitive in appearance. Based upon correlative electrophysiological studies ${ }^{12}$ it seems likely that they are the true site of origin of the pacemaking sinus impulse (Fig. 3). Because of these several attributes of structure and function we have suggested that these small round nodal myocytes be called $P$ cells. ${ }^{11}$

In addition to $P$ cells the sinus node contains many elongated slender myocytes with longitudinally oriented myofibrils and more complex intercellular junctions. We have designated these as transitional cells $^{11}$ for two reasons: they are morphologically intermediate in internal complexity between working

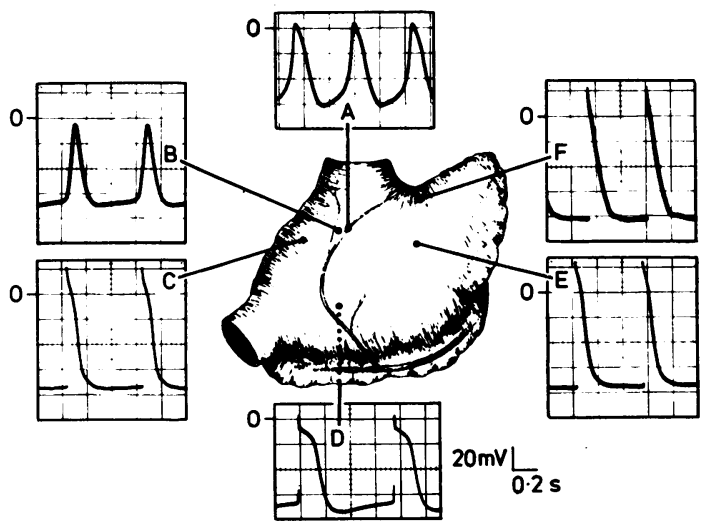

Fig. 3 Drawing to show relation of typical transmembrane action potentials to anatomical sites where they were recorded in and around a canine sinus node which had been studied in vitro and preserved by selective perfusion through the sinus node artery. Details of the study are published elsewhere. ${ }^{12}$ Spontaneous depolarisation from a cell in the mid-sinus node is shown in $A$, from the margin of the sinus node in $B$, from ordinary atrial myocardium in $E$ and $F$, and from internodal pathways in $C$ (middle pathway) and $D$ (posterior pathway).

myocytes and $\mathbf{P}$ cells and they almost certainly function to distribute the sinus impulse from $P$ cells into the atrium. $\mathbf{P}$ cells connect only with other $\mathbf{P}$ cells or transitional cells, whereas transitional cells connect with the atrial myocardium. In contrast to $P$ cells, which typically occur in small grape like clusters predominantly in the central part of the sinus node, transitional cells throughout the node form the slender interweaving fibres characterising the light microscopic appearance recognised by Keith and Flack. There are still other fine structural features of the sinus node such as the disposition of glycocalyx about clusters of $\mathbf{P}$ cells but not between them individually, ${ }^{13}$ which contribute to understanding its special function.

Once the sinus impulse is formed it must then be distributed to the atria and delivered to the atrioventricular node ${ }^{14}$ and thence through the His bundle via its branches to the ventricular myocardium. The history of our knowledge of the conduction system of the heart and how its components integrate so well is a fascinating chapter in medicine. ${ }^{15}$ Very early after the sinus node and atrioventricular node were recognised, there began a debate on the nature of the anatomical routes by which internodal conduction occurred. Two different pathways were proposed by Wenckebach ${ }^{16}$ and Thorel, ${ }^{17}$ and later an interatrial route was described by Bachmann. ${ }^{18}$ Several authorities of the time challenged these findings, notably Mönckeberg, ${ }^{19}$ but the coup de grace was given by Lewis et al. ${ }^{20}$ 
Much of the debate about internodal pathways then and now ${ }^{21-23}$ is based on a distracting insistence, firstly, that if such pathways exist they must be shielded or isolated and, secondly, that they should be comprised exclusively of "specialised" cells (although no one has yet said exactly what is meant by that). Both of these unfortunate misconceptions stem from an arbitrary wish to make internodal pathways of the atria resemble or be identical to the left and right bundle branches of the ventricles, which is in some respects a shibboleth or straw man. Furthermore, the paradoxical truth is that the cellular organisation and composition of the bundle branches themselves are not those of a single cell type, and the right branch is remarkably different in its histological organisation and cellular composition from the left branch. ${ }^{24}$

In the human heart ${ }^{14}$ as well as that of the dog,,$^{25}$ rabbit, ${ }^{26}$ horse, ${ }^{27}$ and cow $^{28}$ there are three distinct pathways for internodal conduction (Fig. 4). None of these is shielded or isolated, and none of them is composed exclusively of "specialised" cells, although each of them does contain many cells with special ultrastructural features (Figs. 5 and 6). ${ }^{29-31}$ As now described by many different observers, ${ }^{32-47}$ those three pathways do form familiar muscular bundles $^{4849}$ such as the crista terminalis, Bachmann's

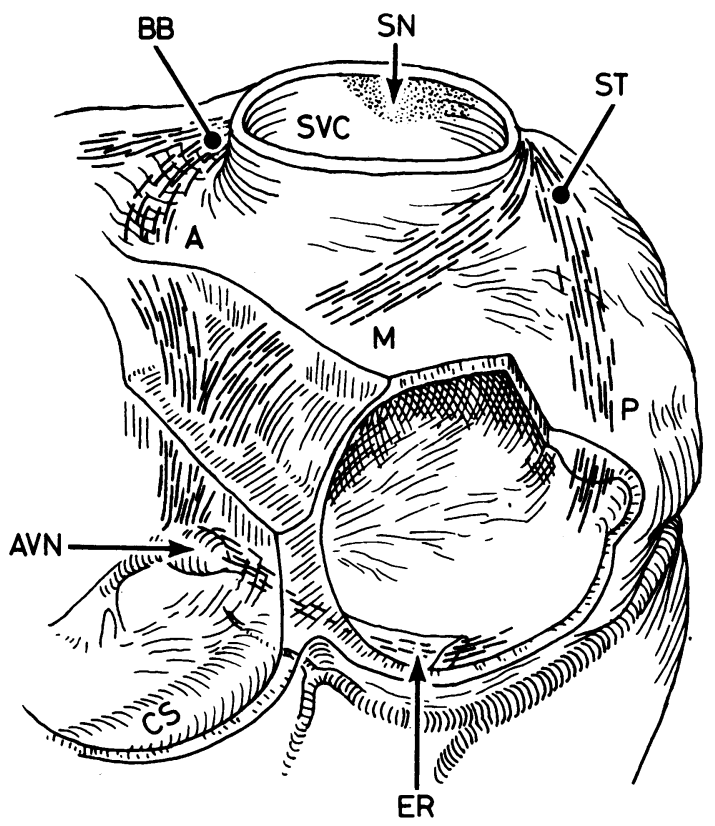

Fig. 4 Drawing showing the course of the three normal intemodal pathways ( $A$, anterior; $M$, middle; $P$, posterior) and their relation to sinus node $(S N)$, sulcus terminalis $(S T)$, Bachmann's buondle $(B B)$, eustachian ridge $(E R), A V$ node $(A V N)$, coronary sinus $(C S)$, and superior vena cava $(S V C)$. bundle (the anterior interatrial myocardial band), the torus Loweri, and the eustachian ridge. Rapid conduction within them 37-394150-57 may indeed be in part due to longitudinal orientation of their component fibres as recently emphasised. ${ }^{58}$ The predominantly linear orientation of fibres is clearly visible even on gross inspection, especially in Bachmann's bundle and in the crista terminalis. But there are likely additional important explanations. Furthermore, it is both incorrect and misleading to say that all the anatomical features of "specialisation" are like Purkinje cells or bundle branches or even that we know very much about what such features must be. For example, few would quarrel with a concept of the sinus node as being specialised tissue, but it contains no Purkinje cells and looks nothing like either bundle branch.

Both experimental and clinical evidence, the combination so dear to Lewis himself, offer strong support for preferential conduction via the internodal pathways. As recently reconfirmed, ${ }^{59}$ poisoning with potassium will arrest atrial mechanical activity but does not stop the sinus impulse from forming nor prevent its conduction to the atrioventricular node. ${ }^{60}$ Supernormal conduction occurs in Bachmann's bundle. ${ }^{5156}$ Certain cells in the internodal pathways have a distinctive transmembrane action potential, ${ }^{61}$ and we have found such cells predominantly within the internodal pathways (Fig. 3), the same areas in which cells with special appearance are located. Cells in the internodal pathways contain an unusual form of myosin. ${ }^{62}$ The property of automaticity found in certain cells in the internodal pathways is the probable basis for so called subsidiary atrial rhythms. ${ }^{63}$ In the human heart studied during and after cardiac surgery there have been repeated reports of preferential atrial conduction in the internodal pathways. ${ }^{64-66}$ Thus the bulk of anatomical, experimental, and clinical evidence supports the concept of preferential atrial conduction through one or more of the three internodal pathways.

Although Lewis held that the sinus impulse spread like fluid poured on a flat surface ${ }^{20}$ or, as some have interpreted, like waves from a pebble tossed into a quiet pond, one of his own important contributions is difficult to explain that way. Harper and Pitt ${ }^{67}$ have recently argued that Lewis may have been the first to describe an unusual example of interatrial block, ${ }^{68}$ an interpretation with which Hollman agreed. ${ }^{69}$ Interatrial block could theoretically be due to arrest of an entire atrium or destruction of many separate connexions, but it is much simpler to conceive of it as being due to interruption of a preferential route. Bachmann's own original experiments dealt with how interatrial conduction could be delayed or prolonged by ligating the anterior interatrial myocardial band, ${ }^{18}$ 



Fig. 5 Light micrographs prepared from sections embedded in epon and stained with toluidine blue illustrating the heterogeneous cellular population of the anterior internodal pathway in Bachmann's bundle of a canine heart. The dark lines in (a) appear to ensheath several Purkinje cells cut in longitudinal section, but this isolation did not persist in other areas. Random orientation of various cells is seen in (b). 


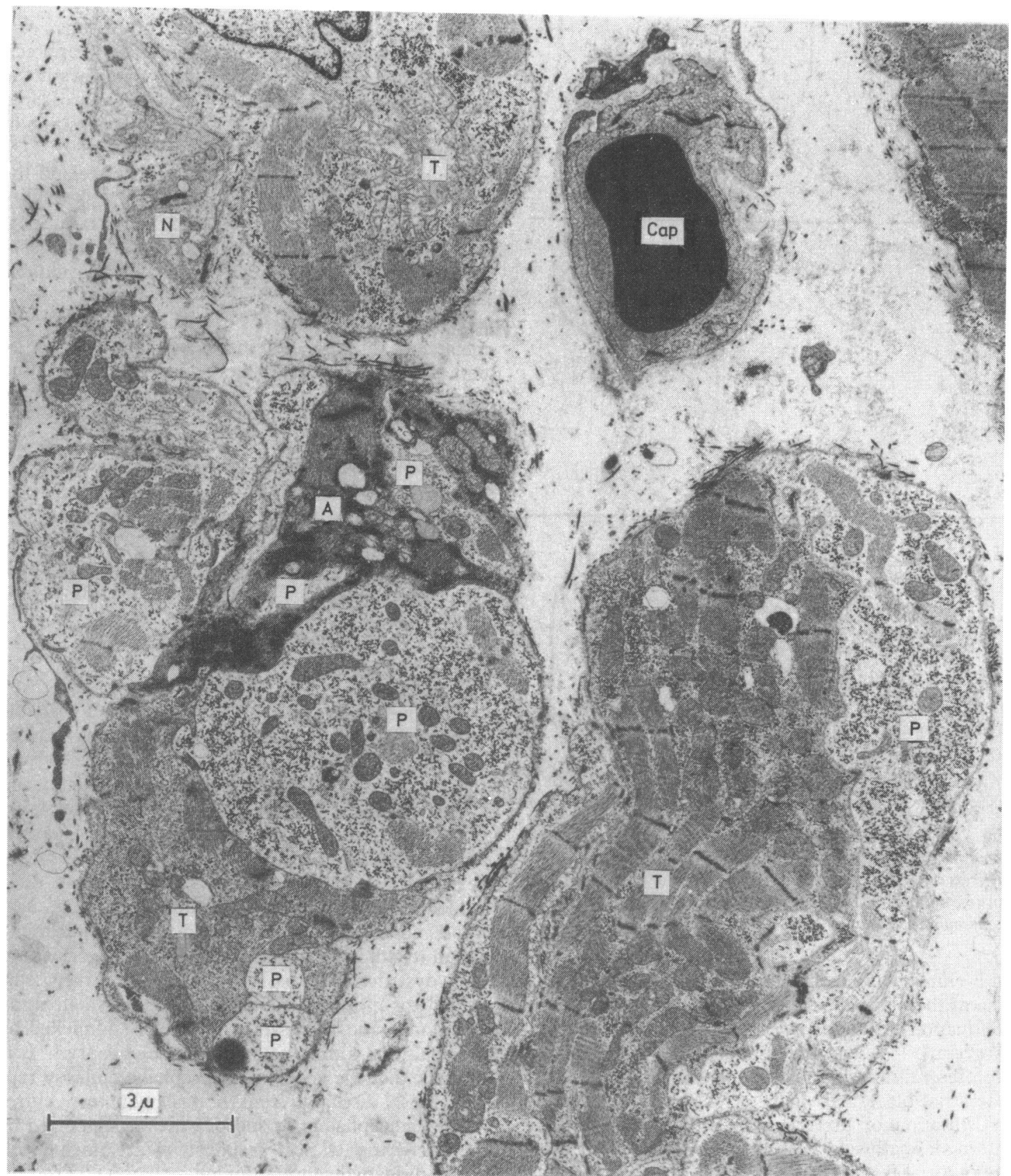

Fig. 6 Electron micrograph of the posterior internodal pathway of a dog showing a remarkable variety of myocardial cells. Different profiles of several $P$ cells are marked $P$ and transitional cells $T$. A unique cell having amoeboid configuration is marked $A$ and is seen intertwined between several $P$ cells. A small nerve is marked $N$ and a capillary Cap. The distinct difference between $P$ cells and transitional cells is well shown. 

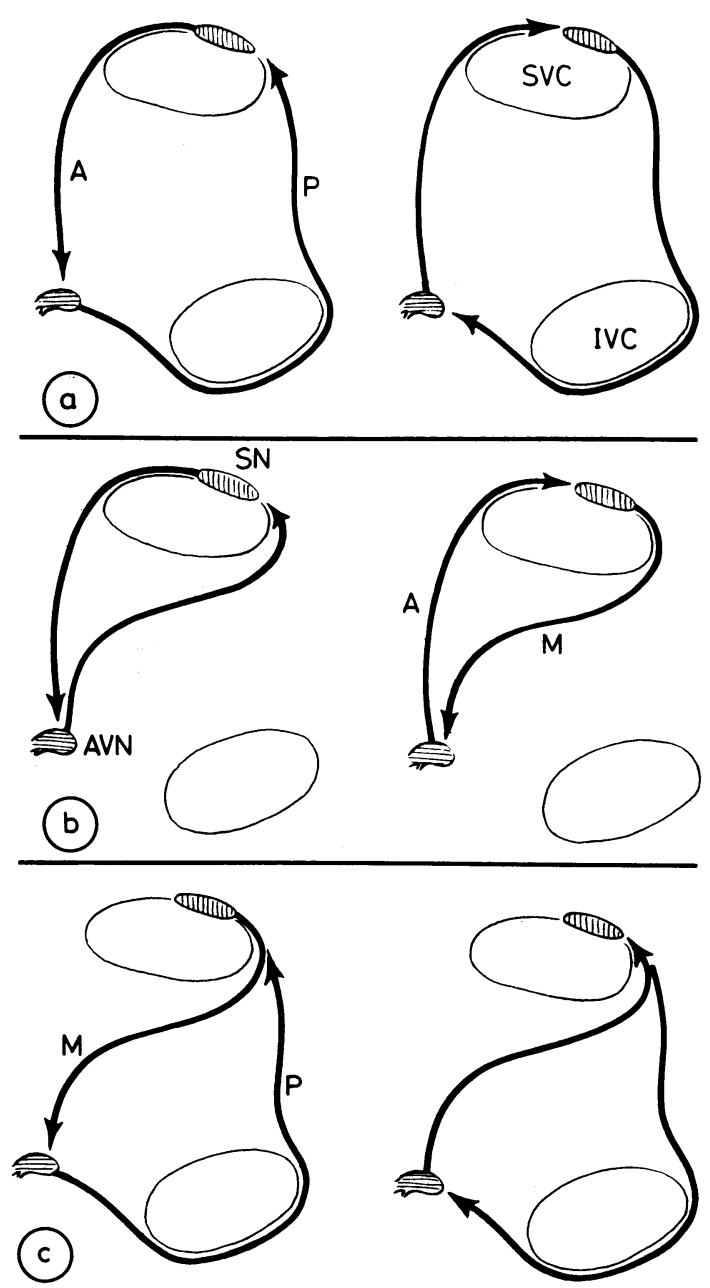

Fig. 7 Diagrams showing the likely routes of circus movement about the superior and inferior venae cavae, utilising the three different internodal pathways in one direction or its opposite, as a possible anatomical substrate for atrial futter. ${ }^{72} 73 \mathrm{See} \mathrm{Fig.} 4$ for additional orientation.

and clinicopathological studies have demonstrated lesions there in patients dying with delayed interatrial conduction expressed as $\mathbf{P}$ mitrale in the electrocardiogram. ${ }^{7071}$ Thus preferential internodal pathways are presently the most plausible explanation for both interatrial block and sinoventricular conduction.

Utilisation of preferential conduction within the internodal pathways has provided a new understanding of atrial flutter. ${ }^{72} 73$ Actually, Lewis's own explanation of circus movement in the atria followed a course around the great veins ${ }^{74} 75$ and fits admirably with the architecture of the internodal pathways (Figs. 4 and 7). The fact that these pathways are punctuated by "natural" obstacles such as the fossa ovalis or the two venae cavae simply contributes to an orientation of the routes by which preferential conduction occurs.

For perhaps the most practical of reasons, cardiovascular surgeons have come especially to appreciate the importance of the internodal pathways if the problem of atrial arrhythmias after the repair of large defects in the interatrial septum or of transposition of the great vessels is to be minimised. $32353676^{-82}$ Furthermore, preservation of the sinus node and the internodal pathways is crucial to the electrical stability of a transplanted heart, ${ }^{83}$ particularly since most escape rhythms are intrinsically unstable ${ }^{84}$ and especially in the denervated state, ${ }^{85}$ which is unavoidable after transplantation.

To return to Lewis's penchant for aqueous metaphors, the spread of atrial excitation may not be best described as resembling the flow of liquid poured on a flat surface nor like the waves caused by a pebble tossed into a quiet pond. Rather, it is like the Gulf Stream in the Atlantic Ocean, not shielded or isolated in a pipe but, nevertheless, a consistent flow within a larger mass of water. Reasons for this preferential distribution of flow, whether in relation to ocean currents or atrial excitation, are only partially understood at present, and improvement of our knowledge about that should be high on the agenda for future electrophysiologists.

\section{Dysautonomia and the heart}

SOLDIER'S HEART AND MITRAL VALVE PROLAPSE "Nervous" symptoms among young soldiers may be fully understandable and appropriate in some circumstances, but they may also occur inappropriately and can be disabling. Difficulty in explaining the palpitation, breathlessness, dizziness, chest pain, paraesthesia, weakness, and occasional syncope has long vexed serious investigators. Da Costa was an early student of this problem, ${ }^{86}$ but its persisting magnitude and seriousness prompted the British army to assign its study to Lewis during the first world war.

A dysautonomic basis could be intuitively suspected for most and perhaps all of these distressing symptoms, and in fact they are closely mimicked by the condition known as diencephalic epilepsy. ${ }^{87}$ It is thought that the spells of diencephalic epilepsy represent focal discharge from the vasoregulatory centres in the diencephalon, a concept which is supported by the gratifying clinical response to treatment with either diphenylhydantoin or phenobarbital. Proof of such focal neural discharge is difficult to obtain since cortical activity of the brain remains normal; however, special encephalographic leads (for example, within the nose) show promise for this purpose. 

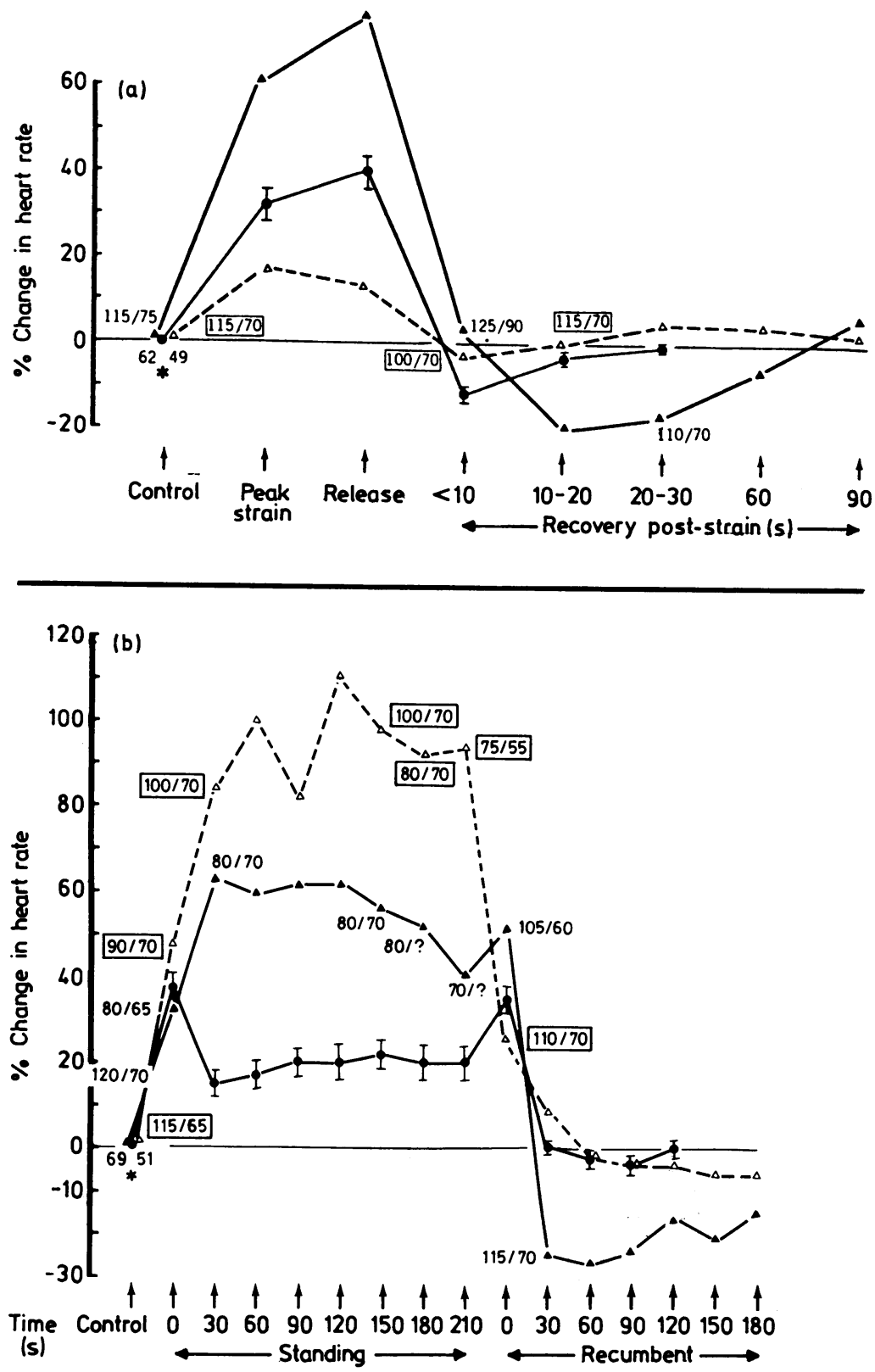

Fig. 8 Effect of four month' treatment with phenobarbital in modifying the abnormal autonomic responses of a young man with mitral valve prolapse and "neurocirculatory asthenia" during a Valsalva manoeuvre $(a)$ and in reponse to tilt $(b)$. With only brief periods of quiet standing he became faint and severely hypotensive before treatment but had no such symptoms after treatment. Concomitant with this clinical improvement, the overshoot abnormalities were completely corrected and both the strain and the standing abnormalities were modulated favourably. Boxed blood pressures are after treatment and others are before. ${ }^{\star}$, resting heart rate from which the changes during testing are plotted; $(O)$, control values $(n=15) ;(\Delta)$ values before treatment; $(\Delta)$ values during treatment with 15 mg phenobarbital four times daily. 
With the remarkable recent clinical interest in mitral valve prolapse, no doubt in large measure attributable to the steady availability-some might say overuse-of echocardiograms, there is growing appreciation that certain of these patients have troublesome symptoms that also represent a form of dysautonomia ${ }^{88-91}$ With simple autonomic tests such as a modified Valsalva manoeuvre and a tilt response, Coghlan and colleagues have demonstrated an assortment of dysautonomic responses in such patients, including abnormal hypotension and inappropriate slowing or acceleration of the heart rate. ${ }^{88}$ Furthermore, selective pharmacological therapy not only improves or abolishes the symptoms but also objectively modifies the abnormal response to autonomic tests (Fig. 8).

Given the very large number of individuals with prolapsing mitral valves, it is well that the great majority have no dysautonomic symptoms. Even in those who do, there is no good evidence that the valve problem and the symptoms are causally related and some evidence ${ }^{92}$ that their coexistence is only happenstance. If either the valve problem or the dysautonomia causes the other, how it happens remains to be explained, although there are some conjectural possibilities. There may be an intriguing analogy in the long QT syndrome, where congenital deafness was a dramatic associated finding in the original description ${ }^{93}$ but in truth may have little or nothing to do with the abnormal repolarisation, cardiac electrical instability, and sudden death. ${ }^{94} 95$

In those individuals with dysautonomia, its aetiology and pathogenesis likewise remain elusive. An otherwise minor bout of encephalitis and subsequent Guillain-Barré syndrome, or some other form of autonomic neuropathy, are both plausible hypotheses but presently no more than that. The recent demonstration that cardioneuropathy, ${ }^{96}$ probably viral, ${ }^{97}$ may be associated with sudden unexpected death adds another dimension to the problem. There are, of course, a multitude of other causes for cardioneuropathy. ${ }^{98}$ Individuals with cardioneuropathy and sudden death, who presumably had a lethal electrical instability of the heart, include those with the long QT syndrome. ${ }^{95}$ The latter condition sometimes responds well to treatment with phenobarbital, ${ }^{99}$ and the mechanism of this benefit could be centrally mediated-for example, by quieting a desynchronising focal discharge from the midbrain. Even though the exact pathogenesis remains poorly understood in most cases, there are clinical markers for some examples of autonomic neuropathy such as that found in patients with diabetes mellitus (Fig. 9).

For conditions as seemingly dissimilar as soldier's heart and the mitral valve prolapse syndrome it now seems likely that dysautonomia is the common fun- damental fault. Furthermore, an untold but possibly large number of "neurotic" patients may be similarly afflicted. It would be sweet irony if many of these uncomfortable and unhappy people, who sometimes respond to treatment with phenobarbital, got much better for a surprising reason-not because of mild sedation per se but because of the fortuitous correction of a serious dysautonomia.

Given that a central fault (diencephalic epilepsy) can produce dysautonomic symptoms, and that individuals recently recovered from certain viral illnesses sometimes develop such symptoms, ${ }^{100}$ both chronic and acute viral infections must be ranked high among suspected causes of "idiopathic" dysautonomia. The site of such infection could be central (brain) or peripheral (heart) or both. But whatever the exact basis for dysautonomia may eventually prove to be, and one would expect that there will be several different causes, dysautonomia is already one attractive and plausible explanation for soldier's heart. ${ }^{101}$

\section{AUTONOMIC STORMS}

When Lewis made the observation that very high blood pressure sometimes appeared during angina pectoris $^{5}$ there was the immediate question of whether the pain itself caused the hypertension. Levine and Ernstene soon answered that by showing that blood pressure rose before pain began. ${ }^{102}$ Although new hypertension appearing during angina pectoris or very early in acute myocardial infarction has been repeatedly confirmed as a clinical observation over the past few decades, how or why it happened was poorly understood.

Then in 1965 Horwitz and Sjoerdsma reported their findings from four patients referred to them for investigation because of severe paroxysmal hypertension suspected to be due to pheochromocytoma. ${ }^{103}$ What they discovered was not pheochromocytoma but that every bout of paroxysmal hypertension occurred just before anginal pain, an elegant confirmation of Lewis's original observation. In a prescient speculation, Horwitz and Sjoerdsma further suggested that a chemoreceptor within the heart might be the origin of the hypertension.

Actually, Comroe had demonstrated a hypertensive chemoreflex in 1939,104 which he attributed to activation of "aortic bodies" even though his own work showed that their blood supply very often came from the coronary arteries. In 1971 Eckstein and his colleagues ${ }^{105}$ contributed two important further observations: firstly, that there was a chemosensitive site with blood supply from the proximal left coronary circulation of the canine heart and, secondly, that hypertension occurred after stimulation with 5-hydroxytryptamine (serotonin), a naturally occurring substance carried in the circulating blood of most 


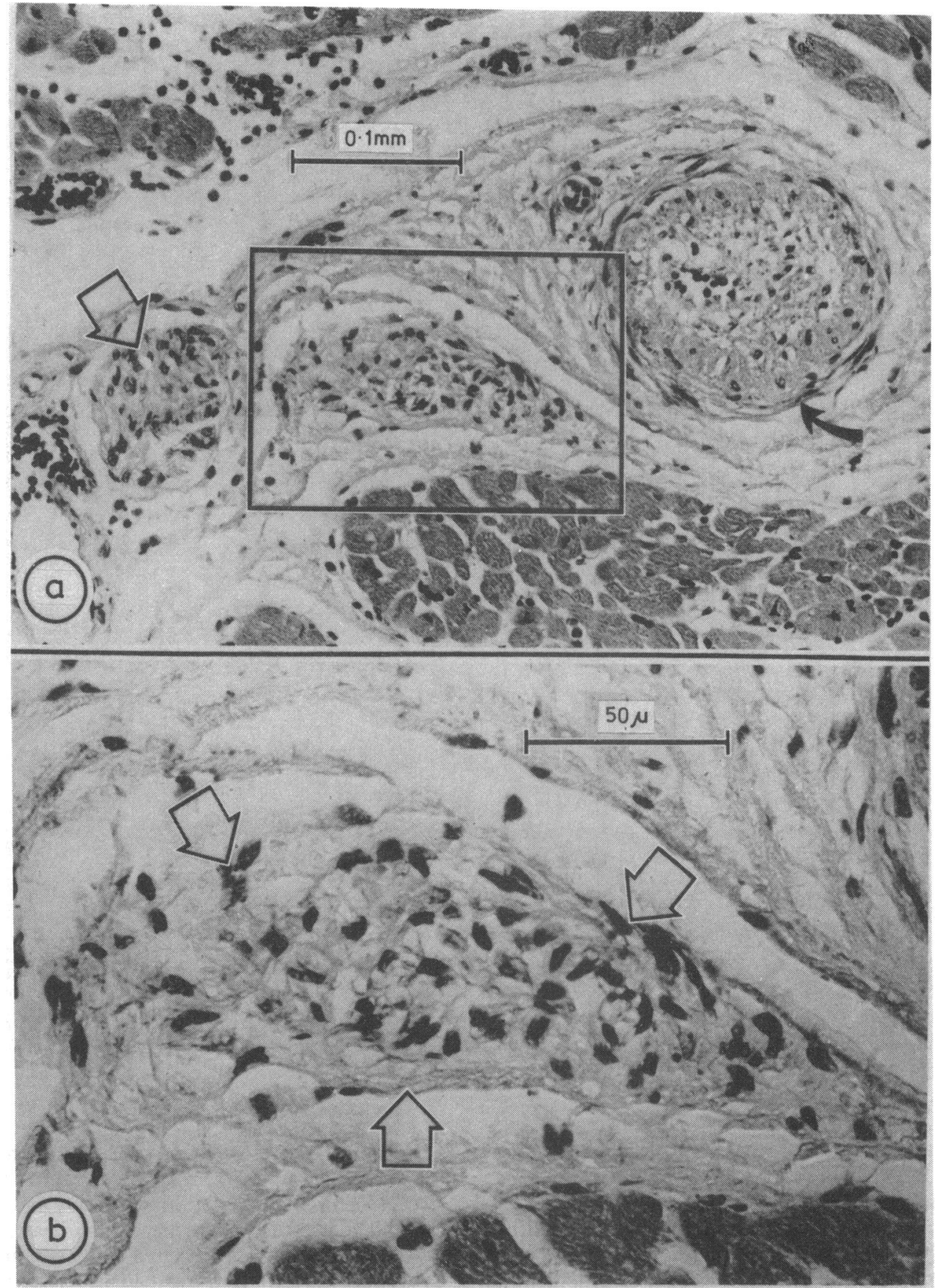

Fig. 9 Histological appearance of both microvascular (curoed arrow in (a)) and neural abnormalities in sections from the heart of a young woman who died with juvenile diabetes mellitus. Boxed area in (a) shows nerve at higher magnification in (b) (three open arrows). An adjacent degenerating nerve is indicated with an open arrow in (a). Goldner trichrome stain. 


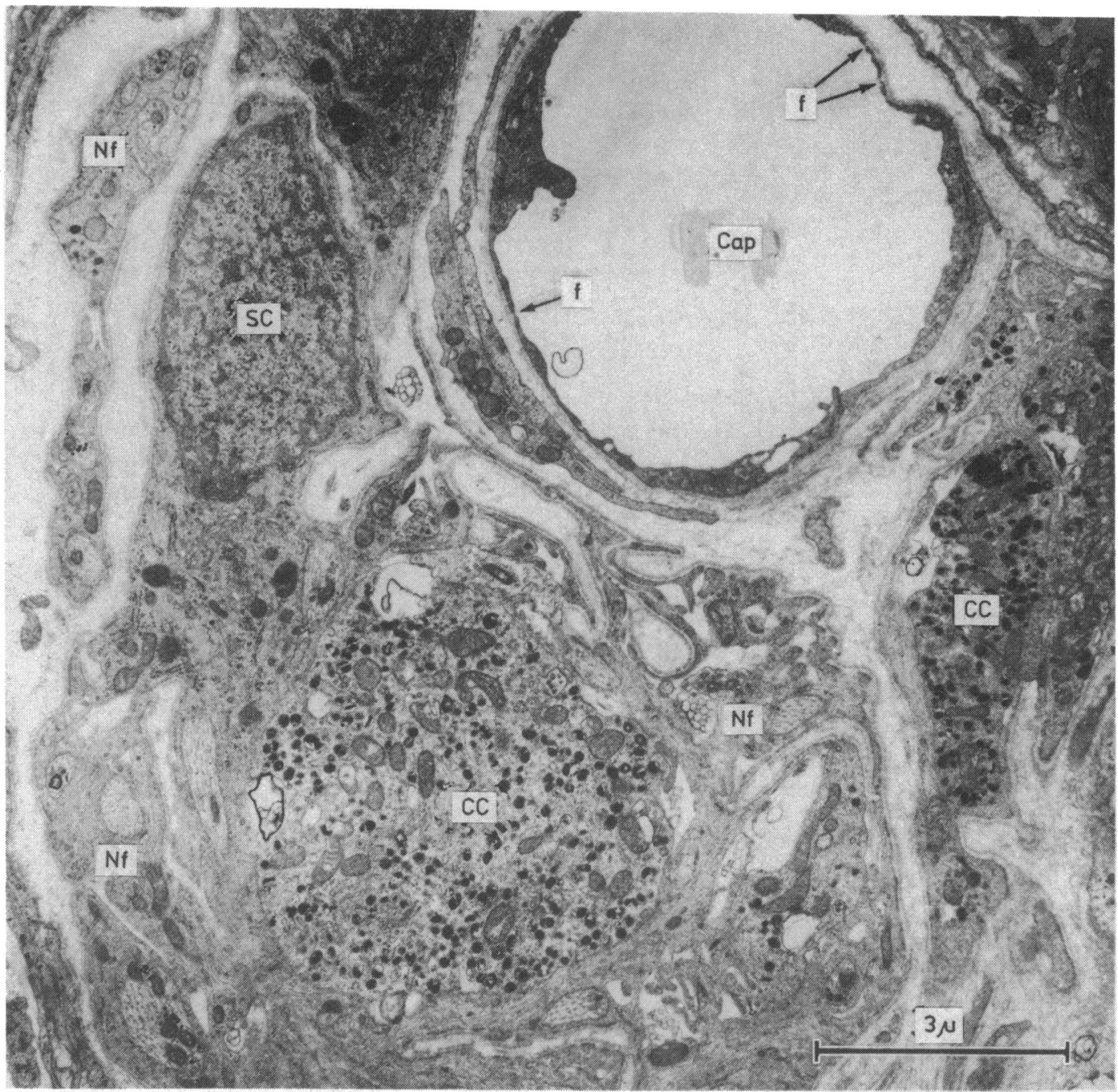

Fig. 10 Electron micrograph showing a coronary chemoreceptor of a dog. Fenestrations $(f)$ in a capillary (Cap) are marked with atrows. Nf, nerve fibres; SC, sustentacular cells; CC, chief cells. The ultrastructure is not distinguishable from that of carotid body even though the response to serotonin is remarkably different.

mammals, including man, which is almost entirely bound to platelets. ${ }^{106}$

Stimulated by these intriguing observations, my colleagues and I embarked on a series of studies of what we have come to call a cardiogenic hypertensive chemoreflex. ${ }^{107}$ Serotonin administered into the distal coronary circulation of the dog produces the BezoldJarisch depressor reflex but when administered into the proximal left coronary circulation of the same animal the same amount of serotonin causes a mirror image response, the most remarkable feature of which is a virtual doubling of aortic pressure within 4-8 s.
In parallel studies we found not only a chemoreceptor with blood supply from the proximal left coronary circulation of the dog but a histologically and anatomically similar structure in the human heart. Several years earlier Anton Becker, in a study conducted for an entirely different purpose, had also described such structures (which he called intertruncal glomera) lying between the origin of the aorta and pulmonary artery in several species including man, and published an exceptionally clear illustration of their blood supply from the main left coronary artery. ${ }^{108}$ At the fine structural level ${ }^{109}$ this chemoreceptor is presently 


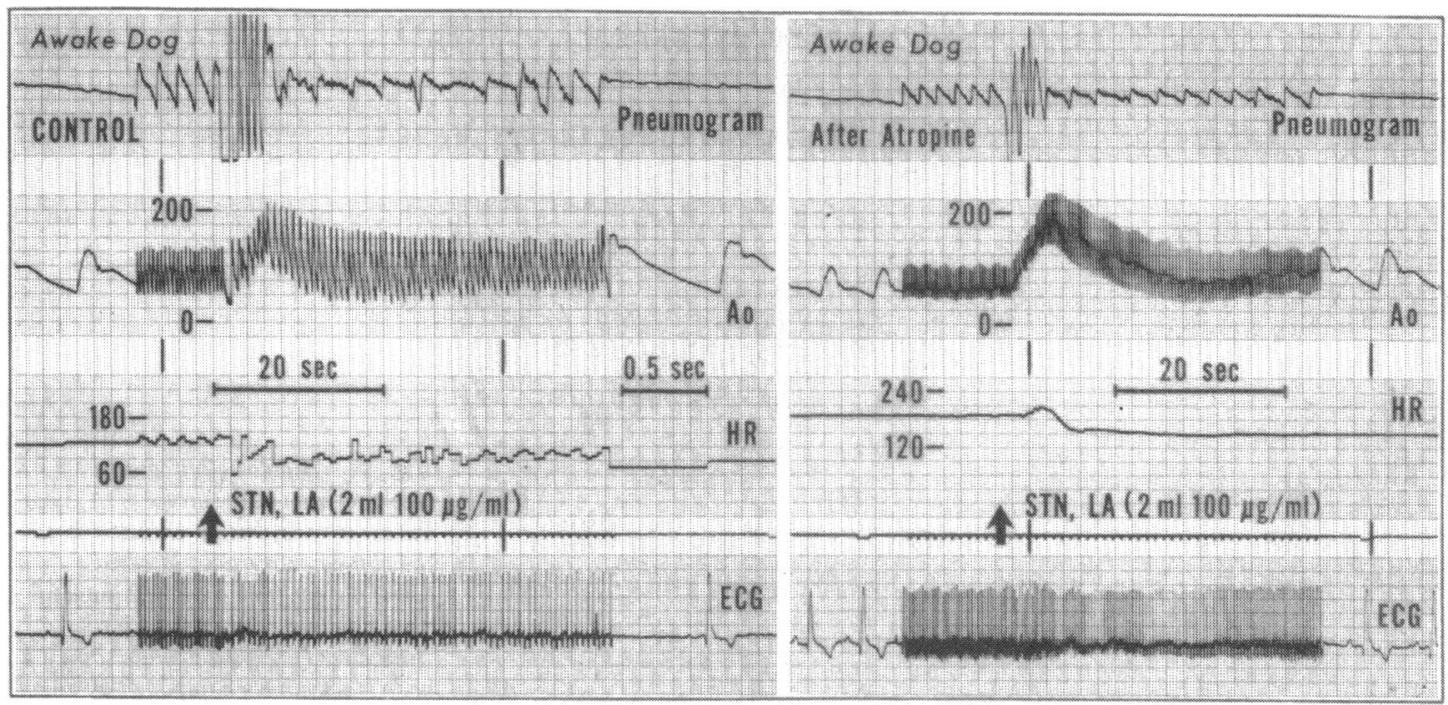

Fig. 11 Cardiogenic hypertensive chemoreflex and associated respiratory changes (see pneumogram) in an awake dog before and afier the administration of atropine. The vagally mediated cardiac slowing is abolished and the hypertensive response accordingly magnified, but breathing changes are similar with or without vagal blockade.

indistinguishable from the carotid body (Fig. 10). In the dog, however, serotonin causes no appreciable response when administered into the carotid artery. 107110 Just what accounts for this anatomical similarity and physiological difference remains to be determined, one possibility being that methods so far used have simply not been adequate to display some fine structural or histochemical difference that actually does exist.

There are other physiological characteristics of the cardiogenic hypertensive chemoreflex. The afferent neural pathway is via thoracic vagal branches, ${ }^{111}$ thus differentiating it from other cardiogenic pressor reflexes which have their afferent course via spinal sympathetic nerves. ${ }^{112}$ Cyproheptadine blocks the reflex at the receptor site but methysergide does not. ${ }^{113}$ During the cardiogenic hypertensive chemoreflex there are simultaneous sympathetic and parasympathetic efferent events, and both are quite powerful. Although the sympathetic events usually predominate, the pronounced hypertension may be delayed several seconds by a transient vagally mediated bradycardia or heart block (Figs. 11 and 12). ${ }^{107114115}$ This vagal component is variable between dogs and even from one time to another in the same dog, but it can be eliminated in both the awake and the anaesthetised state by the administration of atropine (Fig. 11), thus converting the efferent response to one exclusively of hypertension and tachycardia. ${ }^{115}$ In the awake dog a brief period of hyperpnoea is evident (Fig. 11) (which is again a mirror image of the Bezold-Jarisch hypopnoeic effect), but this has no appreciable influence on the hypertension. ${ }^{115}$ In some dogs there is transient atrial fibrillation (Fig. 12) during this brief but powerful vagal influence, and this may be attributed at least in part to the important effect which the vagus nerve has on atrial repolarisation. ${ }^{116}$

Hypertension during the cardiogenic chemoreflex is due to the simultaneous occurrence of arterial vasoconstriction plus a powerful positive inotropic action on both ventricles.117 A negative inotropic effect ordinarily predominates within the atria but is readily converted to a purely positive response after the administration of atropine. Although blood flow sharply decreases in the femoral and mesenteric circulations, little effect occurs in the pulmonary circulation, and there is a conspicuous absence of any coronary effect at all. ${ }^{118}$

As a result of these several different studies, we have teleologically reasoned that the cardiogenic hypertensive chemoreflex may serve a valuable protective purpose. If aggregating platelets in the proximal left coronary circulation are the natural source of serotonin to engage the reflex an abrupt hypertension could disrupt any further organisation of a potentially lethal coronary thrombus. The "stutter" effect seen if there are a few initial vagal pauses may usefully compound the propulsive force of the intermittent powerful contractions (Figs. 11 and 12). In addition to the hypertension newly found during angina pectoris or very early in acute myocardial infarction, the cardiogenic chemoreflex may also participate in the new hypertension seen after coronary bypass grafting ${ }^{119}$ 


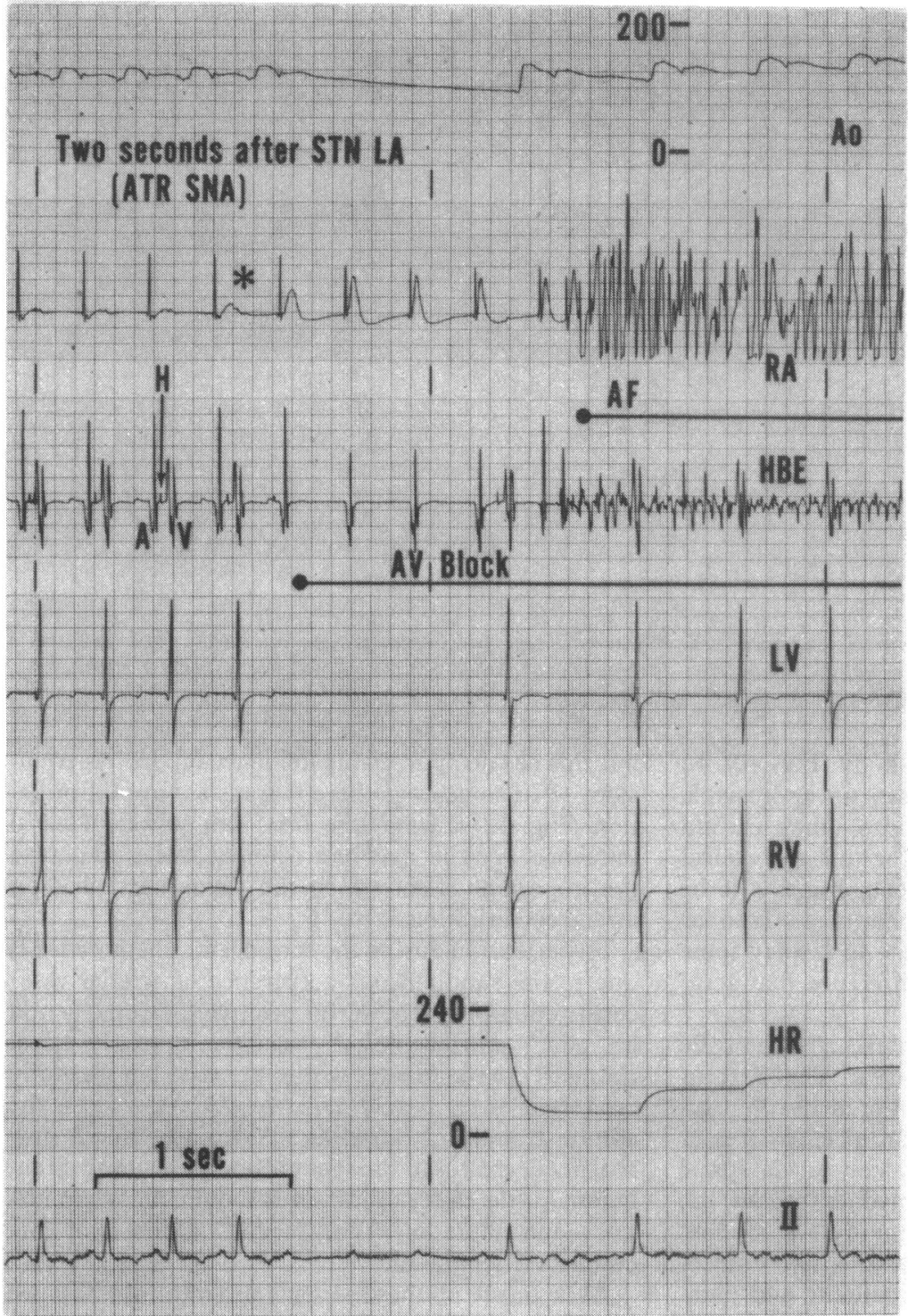

Fig. 12 Bipolar electrograms recorded from right atrium $(R A)$ near the sinus node, from a catheter tip in the nom-coronary sinus of aorta ( $H B E$ ), and from the epicardium of both right $(R V)$ and lefi $(L V)$ ventricles. If response by the sinus node is selectively eliminated by direct perfusion of a very small amount of atropine (10 $\mu \mathrm{g})$, then during the cardiogeric hypertensive chemoreflex there is no sinus slowing, but three other vagal effects remain: transient heart block (atrioventricular node did not get atropine), progressive P-Tp segment elevation (asterisk), and transient atrial fibrillation $(A F)$. Both of the latter two effects represent response from parts of the atria not perfused by the sinus node artery and therefore not receiving any atropine.

and possibly aortic valve replacement, ${ }^{120}$ which appears to be neurally mediated. 121122 Much further study is needed of the exact nature of the phenomenon in man, but today 50 years later we may finally have an explanation for Lewis's accurate clinical observation of "autonomic storms."

\section{Small arteries of the heart}

Lewis could have been drawn to studies of the microcirculation as a logical consequence of his work with neurocirculatory asthenia (soldier's heart) and the obvious importance of small vessels in the control of the vascular system by the nervous system. I am not aware that he was much interested in the small arteries of the heart, but knowledge of their structure and function fits naturally with his much broader orientation.

It is unfortunate that during decades of growing interest in normal and abnormal structure of coronary arteries the focus has been so predominantly on the large branches. Several factors may help to explain 




Fig. 13 Photomicrographs of sections from a patient who died of scleroderma heart disease showing marked narrowing of many small coronary branches ${ }^{128}$ : (a) shows left ventricular myocardium and (b) the atrioventricular node artery. Goldner trichrome stain. 


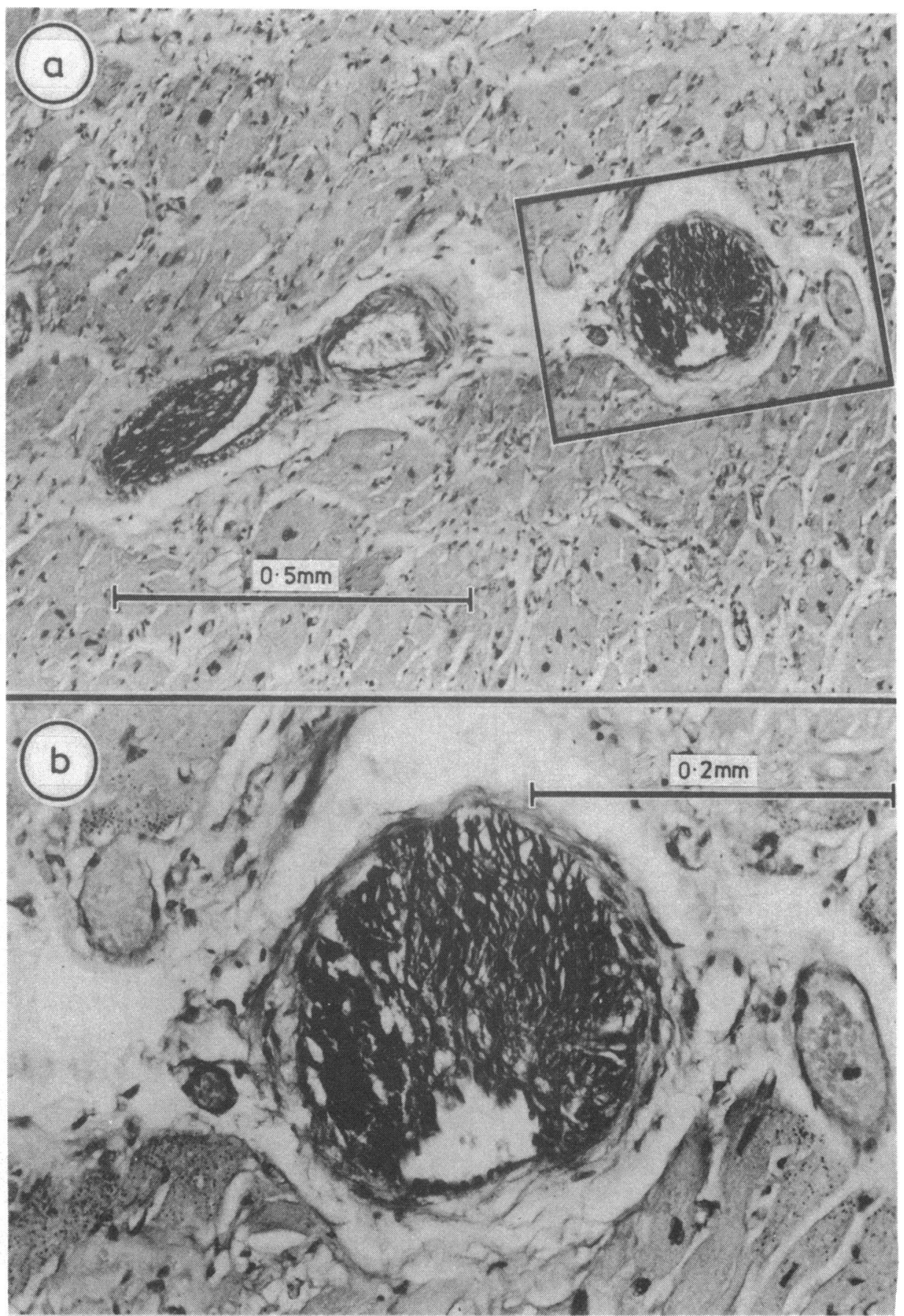

Fig. 14 Histological appearance of cardiomyopathy associated with Friedreich's ataxia ${ }^{125}$ showing widespread narrowing of small coronary arteries with a variety of histological processes. An unusual feature typical of Friedreich's cardiomyopathy seen here at two magnifications ( $a$ and $b$ ) is the intramural deposit of an amorphous periodic acid Schiff positive material. Both $(a)$ and $(b)$ are from sections prepared with the periodic acid Schiff stain. 
this bias. Firstly, the sudden occlusion of large coronary arteries certainly has immediate major consequences which are easy to see and understand. Secondly, there are only a few large coronary branches, and their assessment is not difficult. Thirdly, the myriad of small (1 mm or less in diameter) coronary arteries makes them more difficult to assess; quantification of the extent of small coronary disease, if the entire heart is to be examined, would be a formidable undertaking. Fourthly, most morbid anatomists are unfamiliar with the location and functional role of certain easily found small arteries such as those supplying the sinus node, atrioventricular node, or coronary chemoreceptor.

Through other reasons for a personal interest in these special small coronary arteries supplying the conduction system and the coronary chemoreceptor, I have for over 20 years taken careful note of their condition during clinicopathological correlative studies. ${ }^{123}$ From that orientation one cannot only come to recognise the variety of histological abnormalities (Figs. 13 and 14) that are found, and have the rich opportunity for meaningful functional interpretation because of the specific structures supplied, but also gain an appreciation of the extent and severity of similar abnormalities within other small coronary arteries such as those in the ventricular myocardium. Furthermore, individual variations can be compared because the same special small arteries are examined in each heart. This is not the approach which purists of quantification would choose or at times even condone, but it does offer several practical advantages. A major one is reasonable simplicity and another is common sense interpretation.

If a patient dies suddenly and unexpectedly, or with a known arrhythmia or heart block, and distinct abnormalities are found in the blood supply to the conduction system, it would seem unwise to ignore those rather than to accept a probable causal relation. Then if similar abnormalities are also found in many small ventricular arteries combined with widespread focal myocardial fibrosis, there is strong circumstantial evidence that the small coronary disease was functionally significant in an even broader context.

For some diseases, such as congenital homocystinuria, ${ }^{124}$ Friedreich's ataxia with cardiomyopathy, ${ }^{125}$ and diabetes mellitus, ${ }^{123}$ the narrowing and obliteration of small coronary arteries can be remarkably widespread. The same may be said for amyloidosis of the heart ${ }^{126}$ and for collagen diseases such as polyarteritis nodosa, ${ }^{127}$ scleroderma, ${ }^{128}$ and lupus erythematosus. ${ }^{129}$ Some but not all cases of asymmetric hypertrophy of the heart show widespread small coronary disease. ${ }^{130}$ For most of these examples there is no special predilection for arteries supplying the conduction system to my knowledge, but in some cases of focal fibromuscular dysplasia there may be such a predilection. ${ }^{131} 132$ One of the most intriguing recent discoveries has been the finding of Whipple bacilli (Fig. 15) within the tunica media of small and large coronary arteries and the possibility that these bacteria may be a previously unsuspected cause of chronic degenerative coronary disease. ${ }^{133} 134$

In addition to structural abnormalities of small coronary arteries there are problems due to their spasm, which is now suspected as a cause of certain forms of cardiomyopathy. ${ }^{135}$ It has furthermore been suggested that scleroderma heart disease may in part represent a "Raynaud's phenomenon" of the heart, ${ }^{136}$ a suggestion which undoubtedly would have pleased Lewis in the light of his own contributions on the subject. 137 Actually, in 1938 Lewis published a beautiful study demonstrating that in patients dying of scleroderma those with warm hands had normal digital arteries but those with cold hands (Raynaud's phenomenon) had appreciably narrowed digital arteries, ${ }^{138}$ the morphological appearance of which is remarkably similar to that of those in the heart (Fig. 13).

It is presently uncertain how often and under what conditions the spasm of small coronary arteries may be neurally mediated. For example, coronary resistance and coronary flow are not at all affected during one powerful hypertensive chemoreflex, ${ }^{118}$ the coronary circulation being conspicuously spared. In fact, the mechanism of coronary spasm (large or small arteries) cannot be exclusively neurogenic since it has been shown to occur even in the transplanted heart. ${ }^{139}$ If coronary spasm is to be attributed to non-neural local vasoconstrictive substances platelets become the major suspect. Small coronary arteries not only fill with platelets in thrombotic thrombocytopenic purpura, ${ }^{140}$ disseminated intravascular coagulation, ${ }^{141}$ congenital homocystinuria, ${ }^{124}$ and pheochromocytoma ${ }^{142}$ but are also the terminal site for embolic silting when platelets become disaggregated spontaneously or therapeutically from upstream sites within large coronary branches. We have much yet to learn about the mechanism of coronary spasm, including whether it occurs in the same way in different patients or even in the same patient at different times.

When the small coronary arteries are the targets of any progressive narrowing disease a vicious cycle of mutually compounding complications is set in motion (Fig. 16). Each of these complications is intermittently worsened by transient episodes of spasm or temporary obstruction by platelets. Because of these multiple harmful interactions, it is hardly surprising that so many examples of "cardiomyopathy" exhibit a clinical course of inexorably worsening congestive 

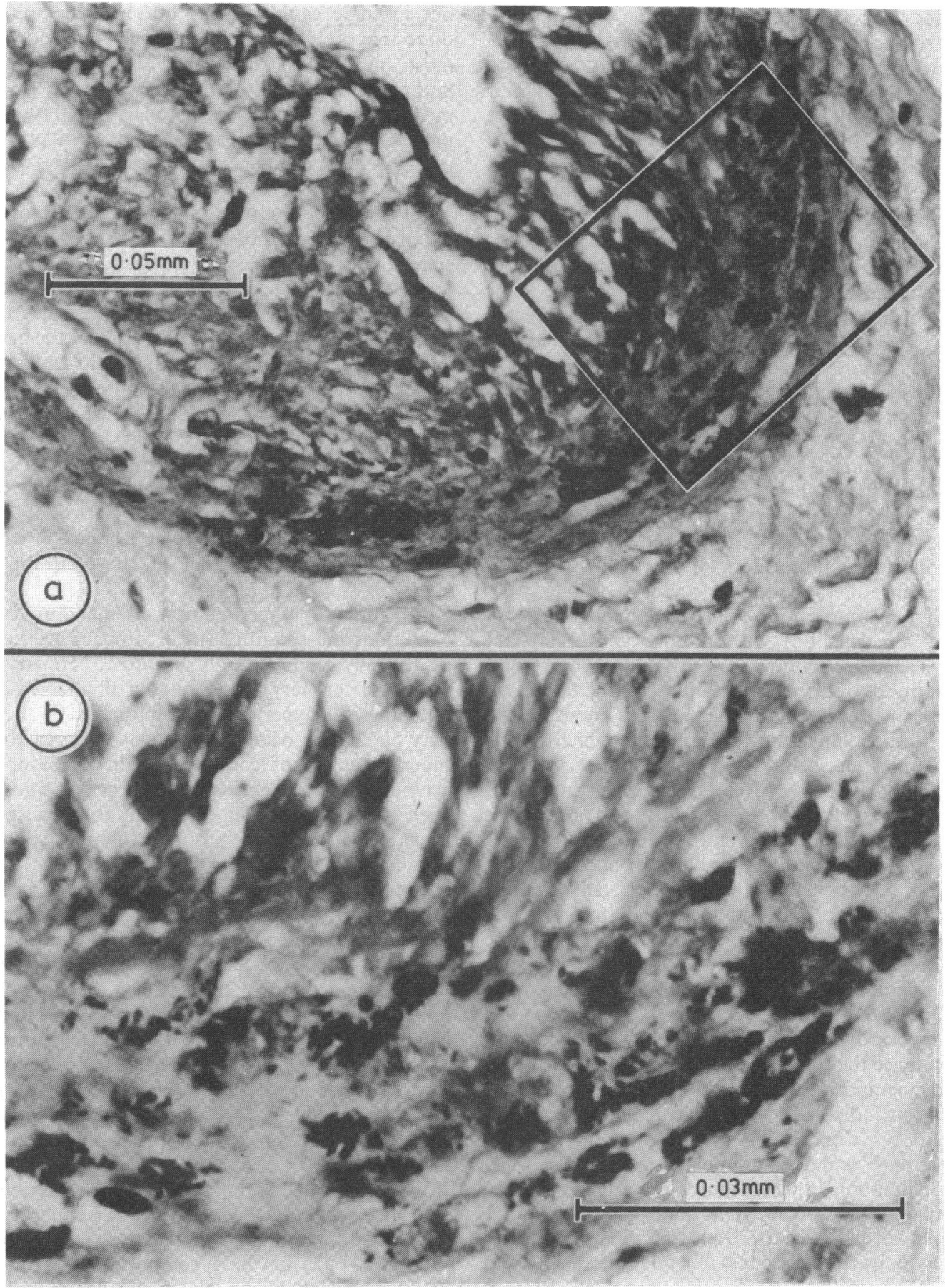

Fig. 15 Photomicrographs showing the presence of periodic acid Schiff positive Whipple bacilli within the turica media of a coronary branch in the left ventricle. Area boxed in $(a)$ is seen at higher magnification in $(b)$, where individual bacilli can be recognised. There is some overlying intimal proliferative response, but the bacilli are predominantly within the turica media. Periodic acid Schiff stain. 


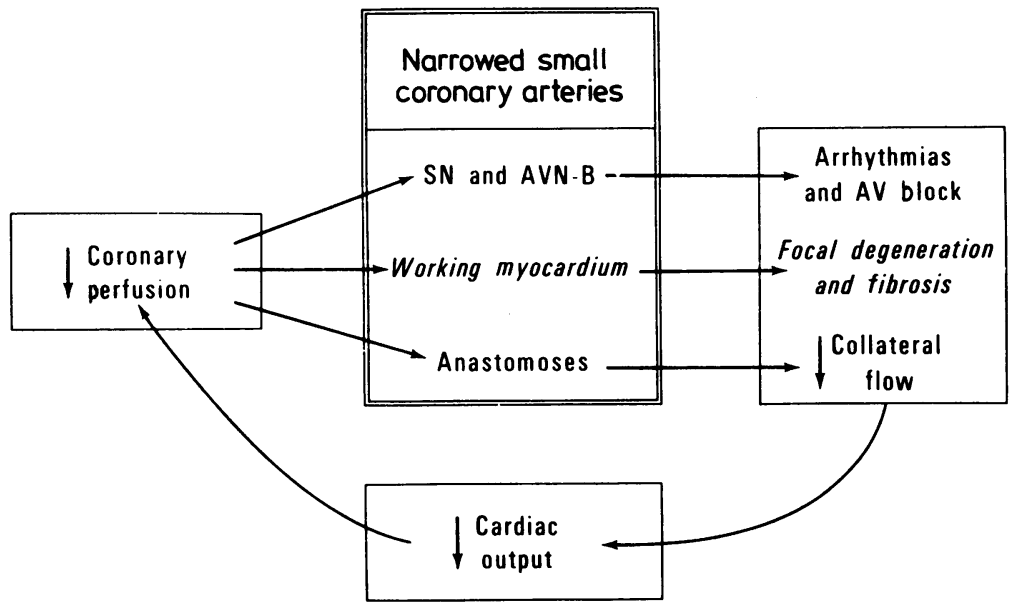

Fig. 16 Schematic diagram showing the sequence of functional consequences which occur during progressive narrowing of small coronary arteries. As more and more arteries are natrowed, even lesser lesions become more clinically significant, and the downhill course is consequently accelerated. $S N$, sinus node; $A V N-B$, atrioventricular node and His bundle.

failure accompanied by arrhythmias, conduction disturbances, and sudden death. ${ }^{143}$

To close this discussion of blood supply to the heart I note with regret that none of us yet knows the exact way in which the pain associated with myocardial ischaemia is produced. ${ }^{144}$ It may be reasonably assumed that some noxious substance or abnormal event stimulates nociceptive nerve fibres in the heart, but what the substance or event may be remains to be discovered. It would help greatly in understanding the alleviation of pain by successful coronary artery bypass grafting, for example, if we knew more about what caused angina pectoris. Lewis had personal reasons for his own research into the mechanisms of pain, ${ }^{145}$ himself suffering from angina pectoris for many years and surviving two myocardial infarctions before dying of the third. ${ }^{2}$ While it is doubtful if today there are better minds to think about the question, we do have the advantage of new concepts and knowledge about coronary physiology and myocardial metabolism and new methods for their study. The fundamental cause of angina pectoris is one of the most challenging opportunities for needed new discoveries through clinical investigation.

\section{Epilogue}

Lewis began his work just after the start of this century and we are now near its end. No one can know what cardiology will be like in the future, but we can already see the lasting value of Lewis's research. Even more, we can be grateful for his teaching us the value of careful scientific experimentation to examine and either confirm or discard clinical hypotheses. That approach, which is the heart of clinical science, will always stand strong in the science of the heart.

There are fascinating lessons to learn by'reviewing
Lewis's career. For example, did he leave the field of electrocardiography too soon? His widely quoted prediction about its limited future could be said to have been poorly considered. But there is a different and infinitely more important lesson which should be a caveat for any clinical investigator. Today, when so many young physicians become enamoured with dazzling technological tools, Lewis stands as an example of the creative scientist who understood how to use technology but not become its slave. What he went on to study was probably more important at the time that anything Lewis could have done with the electrocardiograph then, although of course a decade or two later things changed a great deal in the world of clinical and basic electrocardiography.

Where Lewis excelled and remains an inspiration is in the beauty of ideas, the essence of creativity in any discipline. He was not bound by convention, but he was not reckless with innovation. His research dealt with fundamental biological principles but never strayed far from clinical medicine. To do these things well one must assuredly begin with an original thought, but their successful completion always requires patience, hard work, honesty, and poise with confidence. The best physicians now and in the future can do no better than to emulate Sir Thomas Lewis, but in truth we all know that there will never be many like him.

This paper is based on the 1983 Thomas Lewis Lecture delivered to the British Cardiac Society on 21 November 1983.

The work was supported by grants from the National Heart, Lung and Blood Institute and by the Adele Azar Fund for Cardiovascular Research.

The following figures are reproduced from previous publications as indicated and by permission of the 
respective publishers: Figs. 4-6,29 Dunn-Donnelly Corporation; Fig. 2,11 Fig. 3,12 Fig. 12,107 Fig. 13, ${ }^{128}$ Fig. 14, ${ }^{123}$ and Fig. 15, ${ }^{133}$ the American Heart Association; Fig. 9,98 the American College of Cardiology; Fig. 10,109 Academic Press, Inc; Fig. $11,{ }^{115}$ the C V Mosby Company.

\section{References}

1 Lewis $T$. The nature of flutter and fibrillation of the auricle. Lecture 1-Auricular flutter. $B r \operatorname{Med} \mathcal{F} 1921$; i: 551-5.

2 Pickering GW. In memoriam: Thomas Lewis. Clin Sci 1947-48; 6: 3-11.

3 Lewis T. Report on neuro-circulatory asthenia and its management. The Military Surgeon 1918; 42: 409-26.

4 Lewis T. Vasovagal syncope and the carotid sinus mechanism. With comments on Gowers's and Nothnagel's syndrome. $\mathrm{Br}$ Med F 1932; i: 873-6.

5 Lewis T. Angina pectoris associated with high blood pressure and its relief by amyl nitrite; with a note on Nothnagel's syndrome. Heart 1931; 15: 305-27.

6 Lewis T, Oppenheimer BS, Oppenheimer A. The site of origin of the mammalian heart beat; the pacemaker in the dog. Heant 1910; 2: 147-69.

7 Keith A, Flack M. The form and nature of the muscular connections between the primary divisions of the vertebrate heart. Foumal of Anatomy and Physiology 1907; 41: 172-89.

8 James TN. The sinus node. Am $\mathcal{f}$ Cardiol 1977; 40: 965-86.

9 Söderström N. Myocardial infarction and mural thrombosis in the atria of the heart. Acta Med Scand 1948; suppl 217: 7-112.

10 James TN. The sinus node as a servomechanism. Circ Res 1973; 32: 307-13.

11 James TN, Sherf L, Fine G, Morales AR. Comparative ultrastructure of the sinus node in man and dog. Circulation 1966; 34: 139-63.

12 Woods WT, Urthaler F, James TN. Spontaneous action potentials of cells in the canine sinus node. Circ Res 1976; 39: 76-82.

13 Woods WT, Imamura K, James TN. Electrophysiological and electron microscopic correlations concerning the effects of neuraminidase on canine heart cells. Circ Res 1982; 50: 228-39.

14 James TN. The connecting pathways between the sinus node and the AV node and between the right and left atrium in the human heart. Am Heart $\mathcal{F}$ 1963; 66: 498508.

15 James TN. The development of ideas concerning the conduction system of the heart. Ulster Med F 1982; 51: 81-97.

16 Wenckebach KF. Beiträge zur Kenntnis der menschlichen Herztätigkeit. Archiv fuer Anatomie und Physiologie 1908; 3: 53-86.

17 Thorel C. Ueber den Aufbau des Sinusknotens und seine Verbindung mit der Cava superior und den Wenckebachschen Bündeln. Munch Med Wochenschr 1910; 57: 183-6.

18 Bachmann G. The inter-auricular time interval. $A m \mathcal{F}$ Physiol 1916; 41: 309-20.
19 Mönckeberg JG. Das spezifische. Muskelsystem in menschlichen Herzen. In: Lubarsch O, von Ostertag R, eds. Ergebnisse der Allgemeinen Pathologie und Pathologischen Anatomie des Menschen und der Tiere. Munchen and Wiesbaden: J F Bergmann, 1921: 348474.

20 Lewis T, Meakins J, White PD. The excitatory process in the dog's heart. Part 1. The auricles. Phil Trans $R$ Soc Lond [Biol] 1914; 205: 375-420.

21 Janse MJ, Anderson RH. Specialized internodal atrial pathways-fact or fiction? Eur $\mathcal{F}$ Cardiol 1974; 2: 11736.

22 Anderson RH, Becker AE, Tranum-Jensen J, Janse MJ. Anatomico-electrophysiological correlations in the conduction system-a review. Br Heart $\mathcal{f}$ 1981; 45: 67-82.

23 Southall DP, Keeton BR, Leanage R, et al. Cardiac rhythm and conduction before and after Mustard's operation for complete transposition of the great arteries. Br Heart f 1980; 43: 21-30.

24 James TN, Sherf L, Urthaler F. Fine structure of the bundle branches. Br Heart $\mathcal{F}$ 1974; 36: 1-18.

25 James TN. Anatomy of the AV node of the dog. Anat $\operatorname{Rec} 1964 ; 148: 15-27$.

26 James TN. Anatomy of the cardiac conduction system in the rabbit. Circ Res 1967; 20: 638-48.

27 Bishop SP, Cole CR. Morphology of the specialized conducting tissue in the atria of the equine heart. Anat $\operatorname{Rec} 1$ 1967; 158: 401-16.

28 James TN. Anatomy of the sinus node, AV node and os cordis of the beef heart. Anat Rec 1965; 153: 361-72.

29 Sherf L, James TN. Fine structure of cells and their histologic organization within internodal pathways of the heart: clinical and electrocardiographic implications. Am f Cardiol 1979; 44: 345-69.

30 Madarim-Lacerda CA. Morfometria celular na crista terminalis do coração humano. Arq Bras Cardiol 1983; 40: $177-81$.

31 Emberson JW, Challice CE. Studies on the impulse conducting pathways in the atrium of the mammalian heart. Am Heart f 1970; 79: 653-67.

32 Isaacson R, Titus JL, Merideth J, Feldt RH, McGoon DC. Apparent interruption of atrial conduction pathways after surgical repair of transposition of great arteries. Am $\mathcal{F}$ Cardiol 1972; 30: 533-5.

33 Oosawa M. Histological study on the cardiac conducting systems in the atrial portion of the dog's heart. III. On the specific pathways conducted between the sinus node and the Tawara node. Fpn Circ F 1959; 23: 1014 24.

34 Lev M, Fox SM III, Bharati S, Greenfield JC Jr, Rosen KM, Pick A. Mahaim and James fibers as a basis for a unique variety of ventricular preexcitation. Am $\mathcal{f}$ Cardiol 1975; 36: 880-8.

35 Bharati S, Lev M. Sequelae of atriotomy and ventriculotomy on the endocardium, conduction system and coronary arteries. Am $\mathcal{F}$ Cardiol 1982; 50: 580-7.

36 Bharati S, Molthan ME, Veasy LG, Lev M. Conduction system in two cases of sudden death two years after the Mustard procedure. 7 Thorac Cardiovasc Surg 1979; 77: 101-8.

37 Pereira Leite P, Borelli V, de Brito FS, Andretto R. 
Experimental selective blocks of the internodal conduction pathways in the dog. Revista Faculdade de Medicina Veterinaria E Zootecria da Universidade de Sau Paulo 1976; 13: 421-58.

38 Goodman D, Steen ABM Van Der, Dam RT Van. Endocardial and epicardial activation pathways of the canine right atrium. Am f Physiol 1971; 220: 1-11.

39 Holsinger JW Jr, Wallace AG, Sealy WC. The identification and surgical significance of the atrial internodal conduction tracts. Ann Surg 1968; 167: 447-53.

40 Merideth J, Titus JL. The anatomic atrial connections between sinus and A-V node. Circulation 1968; 37: 566-79.

41 Sano T, Yamagishi S. Spread of excitation from the sinus node. Circ Res 1965; 16: 423-30.

42 Rothberger CJ, Scherf D. Zur kenntnis der erregungsausbreitung vom sinusknoten auf den vorhof. Zeitschrift für die gesamte experimentelle Medizin 1926; 53: 792-835.

43 Lacerda CAM. Dissecação e microscopia óptica dos feixes miocárdicos do septo interatrial humano. Arq Bras Cardiol 1982; 39: 31-4.

44 Doerr W. Morphologische aquivalente bei rhythmusstorungen des herzens. In: Schlegel B, ed. Deutschen Gesellschaft fur innere Medizin. Munchen: J F Bergmann Verlag, 1975: 36-69.

45 Takayasu $M$. Conduction of excitation from the sinus node to the atrioventricular node. Fpn Circ $\mathcal{F}$ 1967; 31: 373-80.

46 Davies MJ, Pomerance A. Quantitative study of ageing changes in the human sinoatrial node and internodal tracts. Br Heart $f$ 1972; 34: 150-2.

47 Rossi L. Histopathology of cardiac arrhythmias. 2nd ed. Plate 1. Philadelphia: Lea \& Febiger, 1978: 2-4.

48 Papez JW. Heart musculature of the atria. Am $\mathcal{F}$ Anat 1920; 27: 254-85.

49 Chuaqui B. Uber die Ausbreitungsbündel des Sinusknotens. Virchows Arch [Pathol Anat] 1972; 355: 179 208.

50 Mirowski M, Lau SH, Wit AL, et al. Ectopic right atrial rhythms: experimental and clinical data. Am Heart f 1971; 81: 666-76.

51 Childers RW, Merideth J, Moe GK. Supernormality in Bachmann's bundle: an in vitro and in vivo study in the dog. Circ Res 1968; 22: 363-70.

52 Wagner ML, Lazzara R, Weiss RM, Hoffman BF. Specialized conducting fibers in the interatrial band. Circ Res 1966; 18: 502-18.

53 Kawamura $K$. An experimental study on the function of atrial specific conduction system in abnormal propagation of excitation. Fpn Circ $\mathcal{F}$ 1968; 32: 63-76.

54 Hayashi H, Lux RL, Wyatt RF, Burgess MJ, Abildskov JA. Relation of canine atrial activation sequence to anatomic landmarks. Am f Physiol 1982; 242: H421-8.

55 Hiraoka M, Sano T. Role of sinoatrial ring bundle in internodal conduction. Am f Physiol 1976; 231: 319-25.

56 Ferrier GR, Dresel PE. Role of the atrium in determining the functional and effective refractory periods and the conductivity of the atrioventricular transmission system. Circ Res 1973; 33: 375-85.

57 Waldo AL, Bush HL Jr, Gelband H, Zorn GL Jr, Vit- kainen $\mathrm{KJ}$, Hoffman BF. Effects on the canine $P$ wave of discrete lesions in the specialized atrial tracts. Circ Res 1971; 29: 452-67.

58 Spach MS, Kootsey JM. The nature of electrical propagation in cardiac muscle. Am 7 Physiol 1983; 244: H3 22.

59 Hariman RJ, Chen C-M. Effects of hyperkalaemia on sinus nodal function in dogs: sino-ventricular conduction. Cardiovasc Res 1983; 17: 509-17.

60 Vassalle M, Hoffman BF. The spread of sinus activation during potassium administration. Circ Res 1965; 17: 285-95.

61 Hogan PM, Davis LD. Evidence for specialized fibers in the canine right atrium. Circ Res 1968; 23: 387-96.

62 Gorza L, Sartore S, Schiaffino S. Myosin types and fiber types in cardiac muscle. II. Atrial myocardium. $\mathcal{F}$ Cell Biol 1982; 95: 838-45.

63 Jones SB, Euler DE, Randall WC, Brynjolfsson G, Hardie EL. Atrial ectopic foci in the canine heart: hierarchy of pacemaker automaticity. Am $\mathcal{F}$ Physiol 1980; 238: H788-93.

64 MacLean WAH, Karp RB, Kouchoukos NT, James TN, Waldo AL. P waves during ectopic atrial rhythms in man. A study utilizing atrial pacing with fixed electrodes. Circulation 1975; 52: 426-34.

65 Waldo AL, MacLean WAH, Karp RB, Kouchoukos NT, James TN. Sequence of retrograde atrial activation of the human heart. Br Heart $\mathcal{F}$ 1977; 39: 634-40.

66 Waldo AL, Hoffman BF, James TN. The relationship of atrial activation to $\mathbf{P}$ wave polarity and morphology. In: Little RC, ed. Physiology of atrial pacemakers and conductive tissues. Mount Kisco, New York: Futura, 1980: 261-89.

67 Harper RW, Pitt A. Thomas Lewis-the early years. Br Heart F 1983; 49: 403-4.

68 Lewis T. Irregular action of the heart in mitral stenosis; the inception of the ventricular rhythm, etc. $Q \mathcal{F} \mathrm{Med}$ 1908-1909; 2: 356-67.

69 Hollman A. Thomas Lewis - the early years. (Reply to Harper and Pitt.) Br Heart F 1983; 49: 404.

70 Beeson CW II, Teabeaut JR II. Bachmann's bundle. Anatomic lesions in $\mathbf{P}$ mitrale [abstract]. Circulation 1969; 40 (suppl III): 42.

71 Eiselsberg K, Zischka-Konorsa W, Busch W. Eine interatriale Reizleitungstörung und ihr pathologischanatomisches Substrat. Zeitschrift fur Kreislaufforschung 1964; 53: 89-96.

72 Pastelin G, Mendez R, Moe GK. Participation of atrial specialized conduction pathways in atrial flutter. Circ Res 1978; 42: 386-93.

73 Moe GK, Pastelin G, Mendez R. Circus movement excitation of the atria. In: Little RC, ed. Physiology of atrial pacemakers and conductive tissues. Mount Kisco, New York: Futura, 1980: 207-20.

74 Lewis T. Observations upon flutter and fibrillation. Part IV. Impure flutter; theory of circus movement. Heart 1918-20; 7: 293-346.

75 Lewis T, Drury AN, Iliescu CC. A demonstration of circus movement in clinical flutter of the auricles. Heart 1921; 8: 341-60.

76 Brandenburg RO Jr, Holmes DR Jr, Brandenburg RO, McGoon DC. Clinical follow-up study of paroxysmal 
supraventricular tachyarrhythmias after operative repair of a secundum type atrial septal defect in adults. Am f Cardiol 1983; 51: 273-6.

77 Arensman FW, Bostock J, Radley-Smith R, Yacoub MH. Cardiac rhythm and conduction before and after anatomic correction of transposition of the great arteries. Am f Cardiol 1983; 52: 836-9.

78 Bink-Boelkens MTE, Velvis $H$, van der Heide JJH, Eygelaar A, Hardjowijono RA. Dysrhythmias after atrial surgery in children. Am Heart $\mathcal{F}$ 1983; 106: 12530.

79 Saalouke MG, Rios J, Perry LW, Shapiro SR, Scott LP. Electrophysiologic studies after Mustard's operation for d-transposition of the great vessels. Am $\mathfrak{F}$ Cardiol 1978; 41: 1104-9.

80 Waldhausen JA, Pierce WS, Berman W Jr, Whitman V. Modified Shumacker repair of transposition of the great arteries. Circulation 1979; 60 (suppl 1): 110-4.

81 Clarkson PM, Barratt-Boyes BC, Neutze JM. Late dysrhythmias and disturbances of conduction following Mustard operation for complete transposition of the great arteries. Circulation 1976; 53: 519-24.

82 Hamilton SD, Bartley TD, Miller RH, Schiebler GL, Marriott HJL. Disturbances in atrial rhythm and conduction following the surgical creation of an atrial septal defect by the Blalock-Hanlon technique. Circulation 1968; 38: 73-81.

83 McGiffin DC, Karp RB, Whelchel JD, Diethelm AG. Cardiac transplanation. A review of the experience of the University of Alabama in Birmingham. Ala $\mathrm{f} \mathrm{Med}$ Sci 1983; 20: 425-30.

84 Rozanski GJ, Lipsius SL, Randall WC. Functional characteristics of sinoatrial and subsidiary pacemaker activity in the canine right atrium. Circulation 1983; 67: 1378-87.

85 Urthaler F, Millar K, Burgess MJ, Abildskov JA, James TN. Comparative dependence on adrenergic neural tone by automaticity in the sinus node and in the atrioventricular junction. F Pharmacol Exp Ther 1973; 187: $269-79$.

$86 \mathrm{Da}$ Costa JM. On irritable heart; a clinical study of a form of functional cardiac disorder and its consequences. Am J Med Sci 1871; 61: 17-52.

87 Geoghegan T, Mueller EJ. Diencephalic autonomic attacks. Report of case with predominantly sympathetic manifestations. $N$ Engl f Med 1952; 247: 841-2.

88 Coghlan HC, Phares P, Cowley M, Copley D, James TN. Dysautonomia in mitral valve prolapse. Am $\mathcal{F}$ Med 1979; 67: 236-44.

89 Gaffney FA, Bastian BC, Lane LB, et al. Abnormal cardiovascular regulation in the mitral valve prolapse syndrome. Am 7 Cardiol 1983; 52: 316-20.

90 Boudoulas H, Reynolds JC, Mazzaferri E, Wooley CF. Mitral valve prolapse syndrome: the effect of adrenergic stimulation. Foumal of the American College of Cardiology 1983; 2: 638-44.

91 Fiorentini C, Olivari MT, Moruzzi P, Guazzi MD. Long-term followup of the primary hyperkinetic heart syndrome: an echocardiographic and hemodynamic study. Am f Med 1981; 71: 221-7.

92 Leor R, Markiewicz W. Neurocirculatory asthenia and mitral valve prolapse: Two unrelated entities? Isr F Med
Sci 1982; 17: 1137-9.

93 Jervell A, Lange-Nielsen F. Congenital deaf-mutism, functional heart disease with prolongation of the Q-T interval, and sudden death. Am Heart f 1957; 54: 5968.

94 James TN. Congenital deafness and cardiac arrhythmias. Am f Cardiol 1967; 19: 627-43.

95 James TN, Froggatt P, Atkinson WJ Jr, et al. De Subitaneis Mortibus. XXX. Observations on the pathophysiology of the long QT syndromes with special reference to the neuropathology of the heart. Circulation 1978; 57: 1221-31.

96 James TN, Zipes DP, Finegan RE, Eisele JW, Carter JE. Cardiac ganglionitis associated with sudden unexpected death. Ann Intern Med 1979; 91: 727-30.

97 James TN, Imamura K. Virus-like particles associated with intracardiac ganglionitis in two cases of sudden unexpected death. Fpn Heart $\mathcal{F}$ 1981; 22: 447-54.

98 James TN. Primary and secondary cardioneuropathies and their functional significance. Foumal of the American College of Cardiology 1983; 2: 983-1002.

99 Moss AJ, McDonald J. Unilateral cervicothoracic sympathetic ganglionectomy for the treatment of long QT interval syndrome. $N$ Engl f Med 1971; 285: 903-4.

100 Barraclough MA, Sharpey-Schafer EP. Hypotension from absent circulatory reflexes: effects of alcohol, barbiturates, psychotherapeutic drugs and other mechanisms. Lancet 1963; i: 1121-6.

101 Lewis T. The soldier's heart and the effort syndrome. 2nd ed. London: Shaw \& Sons, 1940.

102 Levine SA, Ernstene AC. Observations on arterial blood pressure during attacks of angina pectoris. $\mathrm{Am}$ Heart $\mathcal{F}$ 1933; 8: 323-6.

103 Horwitz D, Sjoerdsma A. Some interrelationships between elevation of blood pressure and angina pectoris. In: Hypertension XIII. Proceedings of the Council for High Blood Pressure Research. New York: American Heart Association, 1965: 39-48.

104 Comroe JH Jr. The location and function of the chemoreceptors of the aorta. Am $\mathcal{F}$ Physiol 1939; 127: 176-91.

105 Eckstein RW, Shintani F, Rowen HE Jr, Shimomura $\mathrm{K}$, Ohya $\mathrm{N}$. Identification of left coronary blood supply of aortic bodies in anesthetized dogs. $\mathcal{F}$ Appl Physiol 1971; 30: 488-92.

106 Costa JL, Reese TS, Murphy DL. Serotonin storage in platelets: estimation of storage-packet size. Science 1974; 183: 537-8.

107 James TN, Isobe JH, Urthaler F. Analysis of components in a cardiogenic hypotensive chemoreflex. Circulation 1975; 52: 179-92.

108 Becker AE. The glomera in the region of the heart and great vessels. Pathologia Europaea 1966; 1: 410-24.

109 Imamura K, James TN, Scully KT, Hageman GR, Urthaler F. Ultrastructure of a coronary chemoreceptor of dogs and cats. 7 Mol Cell Cardiol 1982; 14: 711-24.

110 James TN, Hageman GR, Urthaler F. Anatomical and physiological considerations of a cardiogenic hypertensive chemoreflex. Am 7 Cardiol 1979; 44: 852-9.

111 Hageman GR, Urthaler F, James TN. Neural pathways of a cardiogenic hypertensive chemoreflex. Am $\mathcal{F}$ Physiol 1978; 235: H345-9. 
112 Malliani A. Cardiovascular sympathetic afferent fibers. Rev Physiol Biochem Pharmacol 1982; 94: 11-74.

113 Hageman GR, Urthaler F, James TN. Cyproheptadine blockade of a cardiogenic hypertensive chemoreflex. Proc Soc Exp Biol Med 1977; 154: 578-81.

114 James TN, Urthaler F, Hageman GR. Reflex heart block. Am F Cardiol 1980; 45: 1182-8.

115 Hageman GR, James TN, Urthaler F. Studies of changes in breathing and blood pressure accompanying a cardiogenic hypertensive chemoreflex compared in conscious and anesthetized dogs. Am Heart $\mathcal{F}$ 1983; 106: 547-53.

116 James TN, Urthaler F, Isobe JH. Neurogenic influence on the atrial repolarization (P-Tp) segment. Am $\mathcal{F}$ Cardiol 1973; 32: 799-807.

117 Urthaler F, Hageman GR, James TN. Hemodynamic components of a cardiogenic hypertensive chemoreflex in dogs. Circ Res 1978; 42: 135-42.

118 Urthaler F, James TN, Hageman GR. Regional flow patterns during serotonin-induced cardiogenic hypertensive chemoreflex. Cardiovasc Res 1980; 14: 169-76.

119 Estafanous FG, Tarazi RC, Viljoen JF, El Tawil MY. Systemic hypertension following myocardial revascularization. Am Heart $\mathcal{F}$ 1973; 85: 732-8.

120 Layton C, Monro J, Brigden W, McDonald A, McDonald L, Weaver J. Systemic hypertension after homograft aortic valvar replacement. A cause of late homograft failure. Lancet 1973; ii: 1343-7.

121 Tarazi RC, Estafanous FG, Fouad FM. Unilateral stellate block in the treatment of hypertension after coronary bypass surgery. Implications of a new therapeutic approach. Am $\mathcal{F}$ Cardiol 1978; 42: 1013-8.

122 Wallach R, Karp RB, Reves JG, Oparil S, Smith LR, James TN. Pathogenesis of paroxysmal hypertension developing during and after coronary artery bypass surgery. A study of hemodynamic and humoral factors. Am F Cardiol 1980; 46: 559-65.

123 James TN. Small arteries of the heart. Circulation 1977; 56: 2-14.

124 James TN, Carson NAJ, Froggatt P. De Subitaneis Mortibus. IV. Coronary vessels and conduction system in homocystinuria. Circulation 1974; 49: 367-74.

125 James TN, Fisch C. Observations on the cardiovascular involvement in Friedreich's ataxia. Am Heart $\mathcal{F}$ 1963; 66: 164-75.

126 James TN. Pathology of the cardiac conduction system in amyloidosis. Ann Intern Med 1966; 65: 28-36.

127 James TN, Birk RE. Pathology of the cardiac conduction system in polyarteritis nodosa and its variants. Arch Intern Med 1966; 117: 561-7.

128 James TN. De Subitaneis Mortibus. VIII. Coronary arteries and conduction system in scleroderma heart disease. Circulation 1974; 50: 844-56.
129 James TN, Rupe CE, Monto RW. Pathology of the cardiac conduction system in systemic lupus erythematosus. Ann Intern Med 1965; 63: 402-10.

130 James TN, Marshall TK. De Subitaneis Mortibus. XII. Asymmetrical hypertrophy of the heart. Circulation 1975; 51: 1149-66.

131 James TN, Hackel DB, Marshall TK. De Subitaneis Mortibus. V. Occluded A-V node artery. Circulation 1974; 49: 772-7.

132 James TN, Froggatt P, Marshall TK. Sudden death in young athletes. Ann Intern Med 1967; 67: 1013-21.

133 James TN, Haubrich WS. De Subitaneis Mortibus. XIV. Bacterial arteritis in Whipple's disease. Circulation 1975; 52: 722-31.

134 James TN, Bulkley BH. Abnormalities of the coronary arteries in Whipple's disease. Am Heart $\mathcal{F}$ 1983; 105: 481-91.

135 Factor SM, Minase T, Cho S, Dominitz R, Sonnenblick EH. Microvascular spasm in the cardiomyopathic Syrian hamster: a preventable cause of focal myocardial necrosis. Circulation 1982; 66: 342-54.

136 Bulkley BH, Ridolfi RL, Salyer WR, Hutchins GM. Myocardial lesions of progressive systemic sclerosis. A cause of cardiac dysfunction. Circulation 1976; 53: 483-90.

137 Lewis T. Raynaud's disease. New Engl F Med 1932; 206: 1192-8.

138 Lewis T. The pathological changes in the arteries supplying the fingers in warm-handed people and in cases of so-called Raynaud's disease. Clin Sci 1938; 3: 287319.

139 Buda AJ, Fowles RE, Schroeder JS, et al. Coronary artery spasm in the denervated transplanted human heart. Am f Med 1981; 70: 1144-9.

140 James TN, Monto RW. Pathology of the cardiac conduction system in thrombotic thrombocytopenic purpura. Ann Intern Med 1966; 65: 37-43.

141 James TN, Marshall ML, Craig MW. De Subitaneis Mortibus. VII. Disseminated intravascular coagulation and paroxysmal atrial tachycardia. Circulation 1974; 50: 395-401.

142 James TN. De Subitaneis Mortibus. XIX. On the cause of sudden death in pheochromocytoma, with special reference to the pulmonary arteries, the cardiac conduction system and the aggregation of platelets. Circulation 1976; 54: 348-56.

143 James TN. An etiologic concept concerning the obscure myocardiopathies. Prog Cardiovasc Dis 1964; 7: 43-64.

144 Harrison TR. Some problems in the diagnosis, management and pathophysiology of angina pectoris. The John Kent Lewis Memorial Lecture. Arch Intern Med 1966; 117: 323-9.

145 Lewis T. Ischaemia of muscle as cause of anginal pain. Lancet 1931; i: 1138-9. 